\title{
Gaya hidup penggunaan kartu kredit masyarakat urban di Surabaya
}

\section{Lifestyle and the use of credit cards among urban people in Surabaya}

\author{
R. Nurcahya Pramuhadi ${ }^{\bowtie}$ \\ Departemen Sosiologi, Fakultas Ilmu Sosial dan Ilmu Politik, Universitas Airlangga \\ Surabaya, 60286, Jawa Timur, Indonesia \\ E-mail of corresponding author: r.nurcahya.pramuhadi-2014@ fisip.unair.ac.id
}

\begin{abstract}
Abstrak
Kartu kredit merupakan salah satu pendukung dan pemicu percepatan budaya baru. Lembaga keuangan khususnya perbankan berlomba untuk memberikan berbagai fasilitas produk yang menunjang gaya hidup masyarakat modern tersebut, yaitu dengan memberikan penawaran produk kartu kredit yang didalamnya terdapat berbagai macam kemudahan serta keuntungan. Pada hakikatnya masyarakat yang memiliki kartu kredit cenderung konsumtif karena menganggap bahwa uang yang didapat adalah miliknya sendiri padahal uang tersebut merupakan titipan dari pihak bank yang mengambil keuntungan dari penggunaan kartu kredit berupa angsuran, bunga, dan administrasi lain. Metode penelitian yang digunakan ialah kualitatif. Hasil penelitian ini menunjukkan cara masyarakat dalam menggunakan kartu kredit yang dapat mempengaruhi pola konsumsi menjadi lebih boros demi memenuhi gaya hidup. Kaitan antara gaya hidup dan penggunaan kartu kredit terdapat pada penggunaan uang, perilaku masyarakat setelah diterbitkannya kartu kredit menjadi tidak transparan terhadap beban bunga dan cara memakai yang tidak ekonomis.
\end{abstract}

Kata kunci: gaya hidup; kartu kredit; perilaku konsumtif; kaum urban; transaksi ekonomi

\begin{abstract}
Credit cards are one of the facilitators and triggers of the acceleration of new cultures. Financial institutions, especially banks, are racing to provide varying facilities and products to support the lifestyle of modern society, namely by providing credit cards that offer a variety of facilities and advantages. People who have credit cards tend to be consumptive because they think that the money is theirs when the money is in fact a deposit from the banks taking profit from the use of credit cards in form of installment, interest, and administration fees. This study was designed as qualitative research to explore how people in Surabaya use their credit cards, which can result in a more extravagant consumption pattern to meet lifestyle demands. The connection between lifestyle and the use of credit cards is in the use of money. The study also finds changes in the credit card holders' behavior after the issuance of the card. This is due to non-transparency of the interest expenses and uneconomical use of the card.
\end{abstract}

Keywords: lifestyle; credit card; consumptive behaviour; urbanites; economic transactions

\section{Pendahuluan}

Dalam kehidupan sehari-hari manusia selalu berusaha untuk memenuhi kebutuhannya secara terus menerus, karena memang pada dasarnya manusia tidak lepas dari kebutuhan dan tidak akan pernah puas. Kebutuhan manusia dapat terpenuhi salah satunya melalui kegiatan konsumsi, dimana konsumen akan mengalokasikan kekayaanya untuk pemenuhan kebutuhan. Konsumen mengonsumsi kebutuhan tersebut juga didasari faktor-faktor pendukung, yang mencakup pendapatan yang tinggi dan kebiasaannya atau gaya hidup setiap konsumen (Setiadi 2008; Schiffman \& Kanuk 2007; Sutriati et al. 2018; Fadila 2017).

Seluruh lapisan masyarakat selalu menghambur-hamburkan, memboroskan, mengeluarkan, dan mengonsumsi kebutuhan yang paling kecil sehingga sangat penting untuk alasan yang sederhana karena berada dalam konsumsi kelebihan (surplus) konsumsi barang tambahan karena individu seperti masyarakat, merasa tidak hanya ada tetapi hidup dan konsumsi ini dapat berjalan sampai pada tahap kelesuan (Baudrillard 2004). Sama halnya seseorang akan terus menambah proporsi konsumsinya sebanding dengan tingkat pertambahan dari penghasilan yang diterimanya sampai batas tertentu, penambahan pendapatan tidak lagi menyebabkan bertambahnya jumlah makanan yang dikonsumsi 
karena pada dasarnya kebutuhan manusia akan makanan mempunyai titik jenuh. Terdapat kecenderungan bahwa semakin tinggi pendapatan seseorang, semakin berkurang persentase pendapatan yang dibelanjakan untuk makanan. Pendapatan seseorang merupakan salah satu faktor yang sangat berpengaruh dengan kegiatan konsumsi, dikarenakan konsumsi berbanding lurus dengan pendapatan. Semakin tinggi penghasilan yang diterima seseorang maka akan cenderung semakin besar pengeluaran yang digunakan untuk konsumsi.

Kebutuhan hidup manusia selalu berkembang sejalan dengan tuntutan zaman, tidak sekedar untuk memenuhi kebutuhan hidup saja, akan tetapi juga menyangkut kebutuhan lainnya seperti kebutuhan pakaian, rumah, pendidikan, kesehatan dan lain sebagainya. Konsumsi merupakan salah satu kegiatan ekonomi untuk memenuhi berbagai kebutuhan barang dan jasa (Sahrub 2019). Kebutuhan pokok atau kebutuhan dasar merupakan kebutuhan yang sangat penting guna kelangsungan hidup manusia, baik yang terdiri dari kebutuhan atau konsumsi suatu individu maupun keperluan pelayanan sosial tertentu.

Kegiatan konsumsi merupakan kegiatan yang mempergunakan barang atau jasa yang didasari oleh pertimbangan kalkulatif yaitu pertimbangan yang sudah dihitung secara matang mengenai nilai reward yang akan diperoleh (Suyanto 2014). Gaya hidup masyarakat cenderung modern, sebagian orang lebih sering membeli barang-barang di pusat perbelanjaan modern daripada di pasar tradisional (Sugihartati 2010). Diketahui bahwa di Surabaya banyak terdapat pusat perbelanjaan seperi mall, swalayan, minimarket, pertokoan, butik, dan sebagainyaa hingga konsumen akan terdorong untuk berbelanja .

Pada umumnya masyarakat berperilaku konsumtif karena muncul hasrat untuk memiliki suatu barang ataupun jasa yang telah diinginkannya, tak hanya itu suatu barang atau jasa yang dibutuhkan oleh manusia membuat mereka akan berusaha semaksimal mungkin dalam memenuhi dan mendapatkan kepuasannya kembali bilamana mereka berada didalam kondisi terdesak. Namun, keinginan yang tidak selaras dengan kebutuhan tentunya tidak dapat diprediksi kapan atau bagaimana seseorang tersebut akan mendapatkan problem atau konsekuensi yang diterimanya.

Kehidupan masyarakat perkotaan yang tidak terlepas dari gaya hidup yang serba ada. Gaya hidup masyarakat seiring berubah sesuai perkembangan zaman (Chaney 2003). Serta faktor terbesar yang mempengaruhi perkembangan masyarakat perkotaan untuk bisa bertahan hidup adalah meningkatnya kebutuhan individu yang tinggal di dalam kota. Bagi sebagian besar masyarakat di kota-kota besar di Indonesia khususnya di Surabaya, pola konsumsi dan kebutuhan hidup akan kepraktisan, membuat jasa keuangan terutama bank untuk memberikan fasilitas serta pelayanan yang disesuaikan dengan kebutuhan masyarakat tersebut seperti kartu kredit.

Seiring dengan berkembangnya pola konsumsi masyarakat khususnya di perkotaan, perkembangan transaksi dalam kehidupan sehari-hari juga terus mengalami peningkatan serta mengubah kondisi sistem pembayaran dalam transaksi ekonomi. Transaksi ekonomi sekarang ini tidak hanya difasilitasi dengan uang tunai saja tapi telah merambah dengan menggunakan instrumen non tunai secara elektronik. Kemajuan teknologi dalam pembayaran menggeser peranan uang tunai sebagai alat pembayaran kedalam bentuk pembayaran non tunai yang lebih efisien dan ekonomis. Pembayaran non tunai umumnya tidak dilakukan dengan menggunakan uang sebagai alat pembayaran, akan tetapi dapat dilakukan dengan menggunakan kartu ATM, uang elektronik, kartu debet ataupun dengan menggunakan kartu kredit.

Alat pembayaran kini melaju dengan sangat cepat. Sejarah awal munculnya alat pembayaran dengan sistem barter (pertukaran) baik antara berupa barang dengan barang maupun barang dengan jasa atau sebaliknya. Namun masih belum ada kepastian tentang standar dalam barter, dan untuk itu diperlukan ketentuan dan taksiran nilai tukar dengan menciptakan satuan nilai tukar yang disebut uang.

Hingga saat ini, uang masih menjadi salah satu alat pembayaran utama yang berlaku dipergunakan di masyarakat khususnya transaksi dalam jumlah yang kecil. Namun penggunaan uang masih memiliki kendala dalam efisiensi waktu pembayaran serta ketidakpraktisan membawa uang dalam jumlah yang besar. Selain itu, jika melakukan transaksi dalam jumlah yang besar ketika uang harus dibawa, dari 
segi keamanan karena pembawa uang berisiko tinggi dari perbuatan orang-orang jahat, seperti pencurian, perampokan, dan pemalsuan uang. Sehingga mengakibatkan kegiatan penggunaan uang tunai sebagai alat pembayaran mulai berkurang. Maka diperlukan upaya alternatif penggunaan alat tukar yang praktis, efisien dan aman.

Kartu kredit merupakan alat pembayaran pengganti uang tunai yang dapat digunakan oleh konsumen untuk ditukarkan dengan barang dan jasa di tempat-tempat yang dapat menerima pembayaran kartu kredit. Kartu kredit dinilai lebih efektif dan efisien dibandingkan dengan alat pembayaran lain, sehingga lebih dikenal pula ditengah masyarakat. Perkembangan penggunaan kartu kredit yang begitu pesat disebabkan masyarakat merasakan semakin pentingnya penggunaan kartu kredit sebagai alat pembayaran dan mengambil uang tunai mengingat kepraktisan, rasa nyaman, dan aman yang ditimbulkan (Bakhare 2011; Dewi \& Baridwan 2015).

Seiring berkembangnya zaman teknologi, alat pembayaran terus berkembang dari alat pembayaran tunai (cash based) ke alat pembayaran non tunai (non-cash based), yang merupakan pembayaran yang dilakukan tanpa menggunakan uang tunai seperti cek, bilyet giro serta kartu debit maupun kartu kredit. Kartu kredit dapat didefinisikan sebagai transaksi modern dalam bidang ekonomi yang tidak menggunakan uang tunai. Kartu kredit merupakan alat pembayaran melalui jasa bank atau perusahaan pembiayaan dalam transaksi jual beli barang maupun jasa, atau alat untuk menarik uang tunai dari bank serta perusahaan pembiayaan (Subagyo 2005).

Diterbitkannya kartu kredit sendiri berdasarkan perjanjian penerbitan kartu yang dibuat oleh pihak penerbit dan pemegang kartu. Melalui perjanjian tersebut bank atau perusahaan menerbitkan serta menyerahkan kartu berukuran kecil dan terbuat dari plastik yang disebut kartu kredit, yang kemudian dapat dipergunakan dalam berbagai transaksi keuangan. Di dalam praktek penggunaan kartu kredit, ada tiga pihak yang tidak bisa dipisahkan satu sama lain yaitu penerbit kartu, pedagang dan pemegang kartu. Penerbit kartu (issuer) adalah pihak bank/lembaga pembiayaan, pedagang (merchant) adalah pihak penjual barang maupun jasa yang menerima pembayaran dengan kartu kredit dari pemegangnya, sedangkan pihak pemegang kartu kredit (cardholder) adalah pemilik dari kartu yang dipergunakan untuk melakukan pembelian barang maupun jasa.

Alasan lain yang timbul karena masyarakat lebih cenderung menggunakan pembayaran non tunai seperti kartu kredit karena fungsinya sebagai alat ganti pembayaran yaitu kartu kredit dapat dipergunakan sebagai alat ganti pembayaran. Fungsi lain dari kartu kredit adalah sebagai cadangan. Kartu kredit juga dapat digunakan sebagai cadangan untuk keperluan mendadak, seperti jika tiba-tiba ada keluarga yang sakit dan perlu di rawat yang pembayarannya bisa menggunakan kartu kredit atau biaya sekolah yang harus dibayarkan apabila tidak memiliki modal maka kartu kredit solusi yang dapat meringankan beban biaya. Serta fungsi kartu kredit sebagai alat untuk membantu melakukan pembayaran atas tagihan rekening rumah tangga, Pada kartu kredit ada fasilitas one bill, artinya kita bisa meminta kepada Bank penerbit kartu kredit untuk sekaligus membayarkan tagihan atas rekening listrik, tagihan telepon atau handphone, tagihan PAM, tagihan internet serta tagihan-tagihan lainnya dengan sepengetahuan intansi yang mengeluarkan tagihan tersebut (Sayono 2009). Dengan demikian setiap bulan kita tidak disibukkan membayar ke beberapa instansi, namun pembayaran dapat dilakukan sekaligus melalui kartu kredit secara langsung.

Faktor-faktor lain yang mendorong masyarakat menggunakan kartu kredit karena dorongan gaya hidup serta kepemilikan kartu kredit dianggap dapat meningkatkan gengsi (prestige) selain itu kartu kredit dapat mempermudah masyarakat dalam meringankan pembayaran seperti membeli barang sekarang namun membayar kemudian sehingga dengan mudah memperoleh barang atau jasa yang diinginkannya (Fauzan 2017; Lubis \& Lubis 2012).

Pertumbuhan kartu kredit sangat pesat dapat dilihat dengan banyaknya pasar swalayan dan juga tokotoko kecil yang mulai menerima kartu kredit sebagai alternatif alat pembayaran dibandingkan dengan uang tunai. Selain dari fitur-fiturnya semakin beragam dan berkembang, maka fleksibilitasnya juga sudah sangat tinggi. 
Koperasi Kepengurusan Kartu Kredit yang memiliki berbagai macam nasabah mengalami permasalahan mengenai kartu kredit yang berhubungan pada penggunaan kartu kredit dengan gaya hidup. Berdasarkan observasi awal penulis penggunaan kartu kredit yang dimiliki oleh nasabah cenderung digunakan untuk kepentingan konsumtif (Jati 2015; Sumarto et al. 2011; Kristianti 2014; Ramadani 2016; Rimenda \& Listiawati 2013). Pemilik kartu kredit mempunyai alasan-alasan yang mendasar dalam menggunakan kartu kredit. Sistem pembayaran tunai dianggap dapat mengurangi kenyamanan dalam melakukan transaksi manakala nilai transaksinya besar. Pembeli merasa mempunyai risiko keamanan yang relatif tinggi (Putri et al. 2017). Oleh karenanya, dunia perbankan menawarkan fasilitas kartu kredit untuk menarik masyarakat menjadi nasabahnya. Dengan kartu kredit, sistem pembayaran menjadi lebih praktis, cepat, aman dan nyaman. Berbagai macam perilaku pemegang kartu kredit yang muncul dapat disebabkan karena berbagai kemudahan dan fasilitas yang diberikan oleh penerbit kepada pemegang kartu kredit. Hal ini mendorong setiap pemegang kartu kredit dapat memiliki motivasi yang berbeda dalam penggunaan kartu kredit dan perilaku belanja (Themba \& Tumedi 2012; Wickramsinghe \& Gurugamage 2009; Ramayah 2002).

\section{Metode Penelitian}

Metode penelitian yang digunakan dalam penelitian ini adalah metode penelitian kualitatif. Penelitian kualitatif adalah penelitian yang menggunakan latar ilmiah dengan tujuan menafsirkan fenomena yang terjadi dan dilakukan dengan cara melibatkan berbagai metode yang ada (Moleong 2014). Pendekatan ini dilakukan dengan menggunakan wawancara terbuka untuk mendapatkan jawaban yang jelas, dan wawancara ini nantinya akan digunakan untuk memahami sikap, menelaah, melihat pandangan, melihat perasaan, perilaku individu atau sekelompok orang.

Penelitian ini dilakukan di Koperasi Kepengurusan Kartu Kredit yang berlokasi di Jalan Pantai Mentari Kenjeran Selatan Blok A No. 10C, Kecamatan Bulak, Kota Surabaya. Subjek penelitian adalah nasabah Koperasi Kepengurusan Kartu Kredit yang berjumlah 9 orang terdiri dari 6 orang berjenis kelamin laki-laki dan 3 orang berjenis kelamin perempuan serta Non- Nasabah koperasi yang berjumlah 3 orang terdiri dari 2 orang yang berjenis kelamin laki-laki dan 1 orang berjenis kelamin perempuan. Penelitian ini dilakukan di Kota Surabaya mengingat Kota Surabaya sendiri merupakan kota metropolitan yang letaknya sangat strategis menjadikan kota Surabaya sebagai pusat perdagangan maupun kegiatan bisnis sehingga muncul pusat perbelanjaan yang menjadikan masyarakatnya berperilaku konsumtif mengarah pada gaya hidup.

Daya beli masyarakat Surabaya mengalami perkembangan pesat karena didasari oleh faktor kebutuhan yang meningkat pula serta pendapatan daerah Surabaya yang ikut meningkat. Fenomena tersebut menjadi kesempatan bagi lembaga keuangan khususnya bank dengan meluncurkan kartu kredit sebagai upaya memepermudah masyarakat saat berbelanja. Dalam penelitian ini pengumpulan data yang digunakan adalah sumber data primer dan sumber data sekunder. Sumber data primer di peroleh langsung dari subyek yang di teliti (informan), sedangkan sumber data sekunder di peroleh dari keteranga-keterangan orang lain yang mengerti mengenai obyek yang di teliti dan keteranganketerangan dari buku, artikel dan sumber lain yang ada hubungannya dengan obyek yang diteliti. Pada penelitian ini analisis data kualitatif dilakukan dengan fokus utama pada reduksi data, penyajian data, dan penarikan kesimpulan (Sugiyono 2013).

Penyajian data merupakan kegiatan penyusunan data menjadi pernyataan yang memungkinkan penarikan kesimpulan. Penarikan kesimpulan berdasarkan reduksi dan penyajian data. Penarikan kesimpulan dilakukan secara bertahap dari kesimpulan pada tahap reduksi data, kemudian menjadi lebih spesifik pada tahap penyajian data dan makin spesifik pada tahap penarikan kesimpulan di akhir. Data kualitatif diseleksi dan sub-temakan dalam sebuah konfigurasi yang lebih luas yang seluruhnya merupakan sebuah bagian dari proses reduksi data. Analisis diarahkan kepada kecenderungankecendurangan terhadap kesamaan gaya hidup penggunaan kartu kredit masyarakat urban di Surabaya bagi pemegang kartu kredit yang ditemukan sebagai nilai yang tergeneralisir dalam konteks riset studi ini. 
Kerangka pendekatan kualitatif ini menekan bahwa studi ini berusaha memahami pengetahuan dan pemahaman yang terjadi pada pemegang kartu kredit mengacu pada gaya hidup penggunaan kartu kredit masyarakat urban di Surabaya dengan tujuan untuk membongkar dan menangkap dunia subyektif pemegang kartu kredit yang melakukan transaksi tersebut sedalam dan setuntas mungkin, yaitu mengenai mereka mengartikan, mendefinisikan, dan menafsirkan apa yang dilakukanya.

\section{Hasil dan Pembahasan}

Hasil penelitian tersebut menunjukkan bahwa penggunaan kartu kredit terdiri dari beberapa persepsi diantaranya persepsi kemudahan penggunaan merupakan faktor yang menentukan pada persepsi kegunaan dan sikap terhadap penggunaan. Masyarakat pada umumnya menggunakan kartu kredit karena kegunaan yang dianggap praktis dan efektif. Sikap masyarakat yang cenderung memilih kartu kredit karena rasa aman dan nyaman serta masyarakat percaya bahwa penggunaan kartu kredit dapat membantu segala transaksi secara mudah. Penggunaan kartu kredit dapat memberikan prioritas bagi para pemegangnya. Prioritas yang dimaksud adalah keutamaan bagi pemegang kartu kredit yang diterima baik berupa materil maupun immateril. Dari penerimaan prioritas tersebut individu dapat menggunakan kartu kredit dalam memenuhi kebutuhan yang diinginkannya.

Jumlah kartu kredit yang dimiliki setiap informan berbeda-beda. Setiap informan ada yang memilikinya dalam jumlah yang banyak namun adapula yang memiliki kartu kredit sedikit. Akan tetapi penggunaannya memiliki kebutuhan masing-masing. Pemilik kartu kredit dengan jumlah yang banyak biasanya hanya menggunakan kartu kredit dengan plafon/limit tertentu seperti pemakaian kredit untuk konsumsi yang sering digunakan karena sifatnya praktis dan efisien. Setiap pemilik kartu kredit memiliki plafon/limit tertentu tergantung dari bank yang menerbitkan kartu kredit. Plafon tinggi atau rendah ada kaitannya dengan jumlah pemakaian terdahulu serta kewajiban yang dibebankan pemilik kartu kredit selalu tepat waktu pada jatuh tempo. Apabila seseorang sering menggunakan kartu kredit dalam bertransaksi maka plafon/limit yang diberikan juga bertambah bahkan jenis kartu ikut berubah menjadi yang prioritas. Taksiran dari plafon tersebut mendorong informan untuk berbelanja menggunakan kartu kredit hanya untuk mendapatkan keuntungan yang lebih besar.

Jenis kartu kredit menjadi acuan dari tingkat konsumsi pada gaya hidup individu. Kartu kredit dengan level tinggi merupakan kartu kredit dengan plafon/limit tertinggi yang biasanya digunakan untuk keperluan bisnis. Keuntungan dari kartu kredit level platinum jika dibandingkan dengan yang lain memiliki skala prioritas yang lebih besar seperti ruang tunggu khusus, pempelian barang/jasa lebih diutamakan, serta keunggulan pada penawaran. Pemilik kartu kredit dengan level tinggi memiliki gaya hidup yang tinggi pula karena pendapatan yang lebih dari cukup. Jumlah penggunaan kartu kredit dapat dilihat dari banyaknya kartu kredit yang dipakai serta tujuan dari pemakaian kartu kredit tersebut. Seseorang bisa menggunakan kartu kredit lebih dari lima kali karena tuntutan gaya hidup seperti makan di restoran, rekreasi maupun nongkrong di tempat-tempat bergengsi. Salah satu informan menggunakan kartu kredit untuk kepentingan darurat, disaat membutuhkan dana informan tersebut hanya tinggal menggunakan kartu kredit dengan cara gesek tunai (gestun).

Praktis dan efisien menjadi alasan utama para pengguna kartu kredit. Sehingga kartu kredit dianggap lebih mudah dalam urusan transaksi. Seseorang tidak perlu membawa uang dalam jumlah yang besar hanya dengan membawa kartu kredit segala permasalahan transaksi dapat dimudahkan. Tingkat keamanan yang tinggi juga sebagai alasan memiliki kartu kredit. Bagi setiap informan sangat penting membawa kartu kredit karena jika lupa atau tidak membawa uang tunai maka kartu kredit sebagai satu- satunya alat pembayaran.

Setiap informan selalu mempertimbangkan sebelum memiliki kartu kredit dan bukan menjadi alasan sekedar untuk memenuhi gaya hidup. Pemilik kartu kredit harus mengetahui dampak yang akan terjadi apabila memiliki kartu kredit. Berperilaku konsumtif menjadi faktor utama pada permasalahan kartu kredit. Untuk memenuhi gaya hidup, pemilik kartu kredit cenderung membelanjakannya secara tidak teratur, disebabkan karena mereka tidak sadar bahwa uang yang didalam kartu kredit dianggap milik sendiri yang sebenarnya hanyalah titipan dari bank untuk memperoleh bunga. 
Berdasarkan pengamatan peneliti di lapangan, pemegang kartu kredit dengan kategori untuk keperluan mendesak, biasanya dibutuhkan pada saat kebutuhan yang tak terduga muncul secara tiba- tiba seperti pembayaran biaya sekolah beserta tambahannya, biaya perawatan untuk kesehatan, serta segala biaya yang menuntut pemegang kartu kredit untuk melakukan gesek tunai (gestun). Kategori pemegang kartu kredit untuk belanja konsumtif didominasi oleh pihak perempuan dan pemuda yang memiliki kartu kredit. Pemegang kartu kredit perempuan lebih suka menggunakan untuk beanja barang yang sekiranya tidak dibutuhkan demi menjaga prestiseseperti makan di restoran, kumpul-kumpul bersama, maupun belanja barang atau jasa yang berkaitan dengan perawatan diri (kecantikan) sedangkan pemegang kartu kredit di bawah usia 25 tahun juga menggunakan kartu kredit sebagai gaya hidup dalam menjaga prioritas diri serta ingin mendapatkan harga yang lebih murah ketika membeili produk seperti membeli secangkir kopi dengan potongan harga jika menggunakan kartu kredit tertentu.

\section{Simpulan}

Makna gaya hidup penggunaan kartu kredit masyarakat urban sendiri adalah penggunaan kartu kredit yang disertai konsumsi berlebih oleh masyarakat perkotaan khususnya di Surabaya. Motif masyarakat perkotaan dalam penggunaan katu kredit tidak hanya efektivitas dan efisiensi melainkan atas dasar gaya hidup dan penunjukkan status sosial. Motif pemanfaatan kartu kredit oleh masyarakat perkotaan berdasarkan pertimbangan pilihan rasional antara kepentingan, nilai, dan sumber daya yang dimiliki nasabah dalam memanfaatkan kartu kredit tersebut. Kepentingan nasabah dalam mendapatkan kartu kredit dimulai ketika muncul hasrat untuk memiliki maupun mengonsumsi barang atau jasa yang tidak tercapai karena kondisi yang kurang mecukupi sehingga berusaha agar segera terpenuhi dengan cara memiliki kartu kredit.

Kepemilikan kartu kredit juga berkaitan dengan kehidupan masyarakat perkotaan yang tidak terlepas dari gaya hidup yang serba ada. Meningkatnya kebutuhan individu yang tinggal di perkotaan sebagai faktor terbesar yang mempengaruhi perkembangan masyarakat itu sendiri dalam bertahan hidup. Sebagian besar masyarakat perkotaan di Indonesia khususnya di Surabaya membutuhkan pola konsumsi serta kebutuhan hidup akan kepraktisan yang membuat lembaga keuangan terutama bank berupaya menawarkan fasilitas serta pelayanan yang disesuaikan dengan kebutuhan masyarakat seperti kartu kredit. Seiring berkembangnya teknologi dengan pola konsumsi masyarakat khususnya di perkotaan, kegiatan transaksi pada kehidupan sehari-hari juga terus mengalami peningkatan serta mengubah kondisi sistem pembayaran dalam transaksi ekonomi.

\section{Daftar Pustaka}

Bakhare SR (2011) A study on consumer behavior towards credit in Nagpur City. Journal of Banking Financial Services and Insurance Research 1 (4):32-43.

Baudrillard JP (2004) Masyarakat Konsumsi. Yogyakarta: Kreasi Wacana.

Chaney D (2003) Life Styles: Sebuah Pengantar Komprehensif. Yogyakarta: Jalasutra.

Dewi C \& Baridwan Z (2015) Pengaruh sikap, kepercayaan, persepsi kegunaan, persepsi kemudahan penggunaan, dan kualitas sistem terhadap minat masyarakat dalam menggunakan kartu kredit (Studi kasus pada RSUD Dr H. Slamet Martodirdjo Kabupaten Pamekasan). Jurnal Ilmiah Mahasiswa FEB 3 (2):1-21.

Fadila (2017) Hubungan antara pendapatan dan gaya hidup masyarakat dalam pandangan Islam. Mizan: Jurnal Ilmu Syariah 5 (1):39-50.

Fauzan M (2017) Gaya hidup nasabah dan keputusan dalam penggunaan kartu kredit. Sensi: Jurnal Bisnis dan Management 7 (2):181-192.

Jati WR (2015) Less cash society: Menakar mode konsumerisme baru kelas menengah Indonesia. Jurnal Sosoteknologi 14 (2):102-112.

Kristianti DS (2014) Kartu kredit syariah dan perilaku konsumtif masyarakat. Ahkam 14 (2):287-296.

Lubis AH \& Lubis I (2012) Analisis perilaku masyarakat Muslim terhadap penggunaan kartu kredit di Kota Medan. Jurnal Ekonomi dan Keuangan 1 (1):22-35.

Moleong LJ (2014) Metode Penelitian Kualitatif. Bandung: PT Remaja Rosdakarya. 
Putri N, Sasongko W \& Okataviana S (2017) Perlindungan pemegang kartu kredit berkaitan dengan peretasan kartu kredit. Pactum Law Journal 1 (1):65-72.

Ramadani L (2016) Pengaruh penggunaan kartu debit dan uang elekronik (E-Money) terhadap pengeluaran konsumsi mahasiswa. JESP 8 (1):1-8.

Ramayah T, Nasurdin AM \& Choo LH (2002) Cardholder's attitude and bank credit card usage in Malaysia. Asian Academy of Management Journal 7 (1):75-102.

Rimenda T \& Listiawati R (2013) Pengaruh diskon dan penggunaan kartu kredit terhadap compulsive buying. Jurnal Akuntansi, Keuangan dan Perbankan 1 (1):56-60.

Sahrub SMP (2019) Pemaknaan fashion: Studi gaya hidup pada komunitas Indonesia Sneakers Team Surabaya. Jurnal Sosiologi Dialektika 14 (2):103-110.

Sayono JA (2009) Analisis faktor-faktor yang memengaruhi kepemilikan, penggunaan, pembayaran, dan peluang terjadinya gagal bayar dalam bisnis kartu kredit. Jurnal Ekonomi dan Bisnis 3 (1):61-80.

Setiadi JN (2008) Perilaku Konsumen: Konsep dan Implikasi untuk Strategi dan Penelitian Pemasaran. Jakarta: Penerbit Kencana.

Subagyo (2005) Bank dan Lembaga Keuangan Lainnya. Yogyakarta: Bagian Penerbitan Sekolah Tinggi Ilmu Ekonomi YKPN.

Sugihartati R (2010) Membaca, Gaya Hidup dan Kapitalisme. Yogyakarta: Penerbit Graha Ilmu.

Sugiyono (2013) Metode Penelitian Kuantitatif dan Kualitatif R \& D. Bandung: Alfabeta.

Sumarto A, Subroto \& Arianto A (2011) Penggunaan kartu kredit dan perilaku belanja kompulsif: Dampaknya pada resiko gagal bayar. Jurnal Manajemen Pemasaran 6 (1):1-17.

Sutriati, Kartikowati S, \& Riadi RM (2018) Pengaruh pendapatan dan gaya hidup terhadap perilaku konsumtif pada mahasiswa Jurusan Pendidikan Ilmu Pengetahuan Sosial FKIP Universitas Riau. JOM FKIP 5:1-10.

Suyanto B (2014) Sosiologi Ekonomi: Kapitalisme dan Konsumsi di Era Masyarakat PostModernisme. Jakarta: Prenanda Media.

Themba G \& Tumedi CB (2012) Credit card ownership and usage behavior in Bostwana. International Journal of Business Administration 3 (6):60-71.

Wickramsinghe V \& Gurugamage A (2009) Consumer credit card ownership and usage practices: Empirical evidence from Sri Lanka. International Journal of Consumer Studies 33 (1):436-447. 